\title{
Mugifumi, a beneficial farm work of adding mechanical stress by treading to wheat and barley seedlings
}

\author{
Hidetoshi lida * \\ Department of Biology, Tokyo Gakugei University, Koganei-shi, Tokyo, Japan \\ ${ }^{*}$ Correspondence: iida@u-gakugei.ac.jp \\ Edited by: \\ Catherine Coutand, Institut Nationale de la Recherche Agronomique, France \\ Reviewed by: \\ Naomi Nakayama, University of Edinburgh, UK
}

Keywords: mechanical stress, mechanosensing, treading, trampling, stamping, wheat, barley, crop yield

Plant scientists are now aware that mechanical stresses, such as touching, bending and treading, affect the growth and development of trees and grasses, including crops (Jaffe, 1973; Mitchell and Myers, 1995; Telewski, 2006). However, Japanese farmers have known for centuries of the efficacy of applying a mechanical stress-treading, trampling, or stamping - to the seedlings of autumn-sown wheat and barley, and call this process "mugifumi" [mugifúmi] in Japanese. According to a comprehensive, narrative guidebook written in the 17th century, Japanese farmers enthusiastically treaded seedlings in winter because they empirically knew that treading prevented spindly growth, strengthened the roots to grow and spread, shortened plant height, increased tillers and ear length, and eventually gave a good yield (Anonymous, 1680's). Japanese researchers at agricultural experiment stations have described the methodology of treading and many quantitative data on its remarkable effects over the last several decades. However, the information on this practice in English has remained scarce, since it had been targeted to local farmers and written in Japanese only. I here attempted to provide an insight into the significance of treading and advocate the importance of further studies with cutting-edge technology to promote a better understanding of the molecular mechanisms underlying mechanosensing and mechanotransduction in crop plants.

\section{WHAT IS MUGIFUMI?}

Mugifumi is the combination of mugi and fumi. Mugi is the general term for wheat and barley and fumi means treading. Therefore, mugifumi is the act of treading wheat and barley plants, especially their seedlings. In relatively small fields, farmers, their families, and sometimes neighbors tread the seedlings using their feet (Figure 1A), while farmers use an agricultural tractor equipped with a treading roller to tread seedlings in large fields (Figure 1B). Mugifumi is also called "touatsu" [touátsu], which is the combination of tou (treading) and atsu (pressure). Mugifumi is more familiarly used than touatsu.

Mugifumi is known to significantly affect wheat and barley plants. Treated plants have less spindly growth and lodgings, more tillers, longer spikes, and higher yields than untreated plants if farmers perform mugifumi properly.

The timing and number of times mugifumi is performed are important to obtain good results. Special care is needed when performing mugifumi because the growth of wheat and barley varies from year to year and from region to region. This variation depends on wheat and barley varieties and is influenced by yearly and weekly climate changes. If farmers miss the right time and perform mugifumi an incorrect number of times, they may damage the seedlings and have a reduced grain yield. The appropriate weight for mugifumi corresponds to the body weight per seedling.

Wheat and barley seeds are generally sown in the period between November and early December in Japan. Treading is typically started early in January when the seedlings have three leaves, is then performed several times almost every 10 days, and is stopped before internodes start to grow. The number of times treading is performed varies depending on the growth conditions. To avoid letting the soil become too firm, it is important to tread seedlings when the soil is dry. Another beneficial effect of treading is that it permits roots that have risen from the soil due to the growth of frost columns to be settled.

\section{HOW EFFECTIVE IS MUGIFUMI?}

Although many studies have been written in Japanese on the effects of mugifumi on the growth of wheat and barley plants and the yield of gains, to the best of my knowledge, none have been written in English. Of those written in Japanese and available online, a small section of the most comprehensive article written on mugifumi by Ohtani (1950) has been described herein. This article covered a wide range of effects of mugifumi on wheat and barley, including those on developmental, morphological, and physiological traits. I focused on some developmental traits of treaded wheat plants, including grain yields.

Supplementary Table 1 shows the effects of treading on the development of wheat seedlings. In this experiment, the seeds of wheat were sown in a field in the middle of November; seedlings were treaded with feet 32, 62, 73, and 84 days after sowing; and the effects of treading were examined 101 days after sowing. Treading clearly resulted in favorable effects on seedling development from an agricultural viewpoint. Regarding the shoot, the numbers of stems and leaves as well as the wet weight were increased by treading by 74,10 , and $50 \%$, respectively. The length and number of roots were also increased by 4 and $7 \%$, 

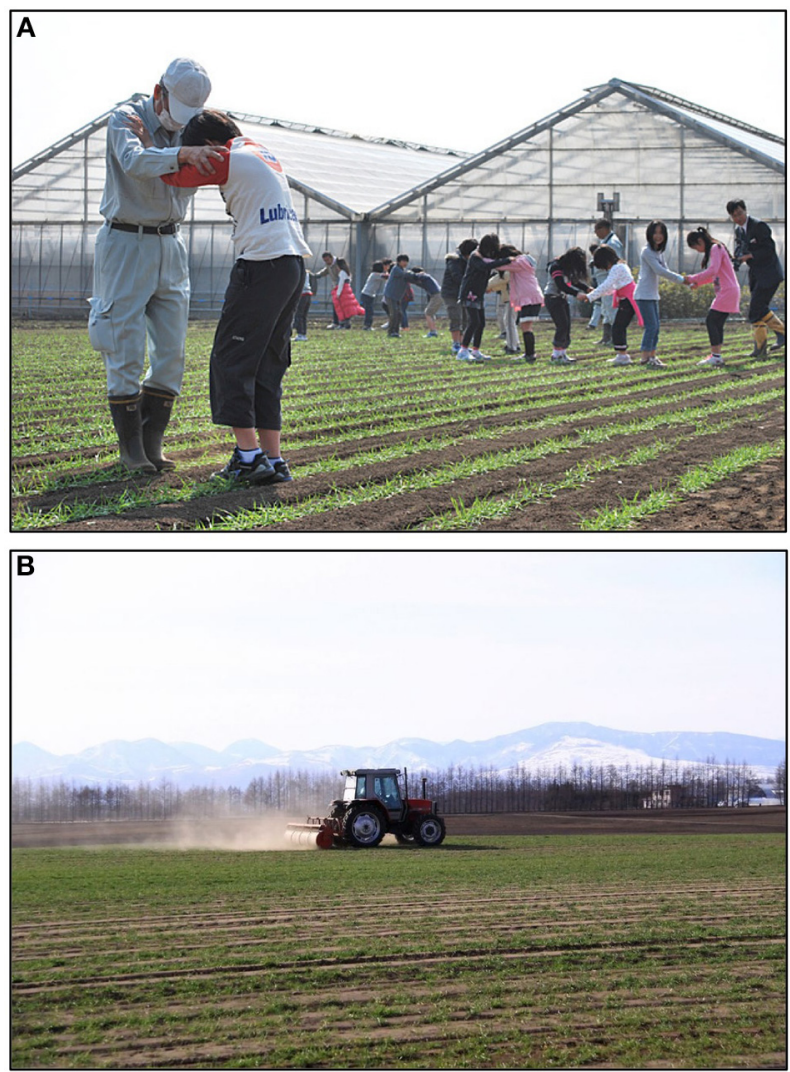

FIGURE 1 | Scene of mugifumi. (A) Are they dancing in the wheat fields? No, they are not. Farmers and their neighboring children tread wheat seedlings (in Fujisawa, Kanagawa Pref., Japan). Courtesy of the Chiikimiryoku, a nonprofit organization. (B) Large-scale treading. Farmers use an agricultural tractor equipped with a specifically designed treading roller to tread wheat seedlings (in Kamishihoro, Hokkaido, Japan). Courtesy of Mr. Haruo Hoshino.

respectively. These findings indicate that treading induces tillering and stimulates the roots to grow and spread. These quantitative findings substantiate the accuracy of the narrative guidebook for farmers described over 300 years ago (Anonymous, 1680's).

Supplementary Table 2 shows the effects of wheat treading on grain yields. In this experiment, seeds were sown on seedbeds near the end of October and the seedlings were transplanted to fields 42 days after sowing. Treading was performed twice on seedlings with feet 151 and 156 days after sowing. This treading led to good yields: the number of spikes per plant, weight of whole plant, and grain weight per plant were increased by 18,41 , and $54 \%$, respectively.

\section{PERSPECTIVE}

These two examples demonstrate that mechanical stress, such as treading, modifies the development and growth of wheat, resulting in higher numbers of stems, leaves, roots, and spikes, all of which increase grain yields. Although data was not shown here, a previous study reported that wounds caused by treading facilitated the evaporation of water and thus increased the osmolality of cells, thereby conferring cold resistance on the treaded seedlings (Ohtani, 1950). The effects of treading were also investigated extensively using botanical, biochemical, and physical approaches more than 60 years ago (Ohtani, 1950). However, further studies are warranted to investigate the effects of treading wheat and barley plants with modern technologies not only from agricultural viewpoints, but also from the aspect of basic science.

Beneficial effects of mechanical stress are not limited to wheat and barley. There are many studies on the effect of mechanical stress on vegetable plants (for review, see Latimer, 1991). For example, rubbed soybean plants exhibited reduction in stem elongation and frost resistance (Jaffe and Biro, 1979). Mechanically rubbed stems of common bean were hardened because of an increase in flexibility and acquired resistance to bending-caused breaking (Jaffe et al., 1984). Wind-induced mechanical stress increased resistance to an arthropod herbivore and a fungal pathogen in common bean (Cipollini, 1997).

Effects of mechanical stress on trees have also been studied extensively (for review, see Coutand, 2010). For instance, mechanical bending of the stem increased biomass allocation toward the root in wild cherry tree seedlings, avoiding the formation of poor root systems and the reduction of diameter growth of the trunk seen in mechanically untreated seedlings (Coutand et al., 2008). Mechanical stress given to the upper part of the order 1 axis of young rose plants resulted in a reduction in axis length and an increase in the number of branching, leading to the compactness of the bush, a favorable horticultural trait (Morel et al., 2012). Thus, it is possible that chemical plant growth regulators or chemical plant growth retardants, which are frequently used in horticulture, can be replaced by an appropriate mechanical stress, that is an environment-friendly treatment. As is the case for mugifumi, however, careful application of mechanical stress is needed in consideration of degree of forces applied, the stage of plant growth, soil conditions, weather, and so on. It is worthwhile to note that those favorable effects of mechanical stress on vegetable plants and trees are similarly seen on wheat and barely as described above.

As for mugifumi, the following future studies would be of interest: treadinginduced early signaling, gene expression, changes in the cytoskeleton and cell wall, hormone synthesis and transport, and changes in metabolism. These researches should provide a novel insight into mechanosensing and mechanotransduction in plants, especially in monocots. Such lines of study have recently been conducted using a model dicot, Arabidopsis thaliana. For example, by whole genome microarray analysis, mechanical wounding 
of leaf tissues was shown to induce a number of rapid wound response genes that overlaps with those induced by a wide range of biotic and abiotic environmental stresses (Walley et al., 2007). Repetitive touching enhanced resistance to fungus (Botrytis cinerea) infection and cabbage looper (Trichoplusia ni) infestation in a defense phytohormone jasmonatedependent manner (Chehab et al., 2012). Gentle mechanical sweeping of leaf surfaces induced a rapid increase in cytosolic $\mathrm{Ca}^{2+}$ concentration and a release of reactive oxygen species, and then enhanced resistance to $B$. cinerea in a jasmonateindependent manner (Benikhlef et al., 2013). Technically and conceptually similar studies on mugifumi-treated wheat and barley should offer a clue to increase the yield of grain and alleviate the shortage of the food worldwide without using a large amount of fertilizers, production and use of which increase environmental burdens.

\section{ACKNOWLEDGMENTS}

I thank Ms. Minori Tanaka of the Chiikimiryoku and Mr. Haruo Hoshino for allowing me to use the photographs and Ms. Yumiko Higashi for her secretarial assistance. This work was supported by Grants-in-Aid for Scientific Research on Priority Area No. 21026009 (to Hidetoshi Iida), No. 23120509 (to Hidetoshi Iida) and No. 25120708 (to Hidetoshi Iida) from the Ministry of Education, Culture, Sports, Science and Technology of Japan, and a Grant-in-Aid for Scientific Research B No. 26291026 (to Hidetoshi Iida) from the Japan Society for the Promotion of Science.

\section{SUPPLEMENTARY MATERIAL}

The Supplementary Material for this article can be found online at: http://www. frontiersin.org/journal/10.3389/fpls.2014. 00453/full

\section{REFERENCES}

Anonymous, (1680's). Hyakusho-denki (Guidebook for Farmers). Vol. 1-15 (in Japanese). Annotated by T. Furushima (1977), Tokyo: Iwanami Shoten Publ.

Benikhlef, L., L'Haridon, F., Abou-Mansour, E., Serrano, M., Binda, M., Costa, A., et al. (2013). Perception of soft mechanical stress in Arabidopsis leaves activates disease resistance. BMC Plant Biol. 13:133. doi: 10.1186/1471-222913-133

Chehab, E. W., Yao, C., Henderson, Z., Kim, S., and Braam, J. (2012). Arabidopsis touch-induced morphogenesis is jasmonate mediated and protects against peasts. Curr. Biol. 22, 701-706. doi: 10.1016/j.cub.2012.02.061

Cipollini, D. F. Jr. (1997). Wind-induced mechanical stimulation increases pest resistance in common bean. Oecologia 111, 84-90. doi: 10.1007/s004420050211

Coutand, C. (2010). Mechanosensing and thigmomorphogenesis, a physiological and biochemical point of view. Plant Sci. 179, 168-182. doi: 10.1016/j.plantsci.2010.05.001

Coutand, C., Dupraz, C., Jaouen, G., Ploquin, S., and Adam, B. (2008). Mechanical stimuli regulate the allocation of biomass in trees: demonstration with young Prumus avium trees. Ann. Bot. 101, 1421-1432. doi: 10.1093/aob/ mcn054

Jaffe, M. (1973). Thigmomorphogenesis: the response of plant growth and development to mechanical stimulation. Planta 114, 143-157. doi: 10.1007/ BF00387472

Jaffe, M. J., and Biro, R. (1979). "Thigmomorphogenesis: the effect of mechanical perturbation on the growth of plants, with special reference to anatomical changes, the role of ethylene, and interaction with other environmental stresses," in Stress Physiology in Crop Plants, eds H. Mussell and R. C. Staples (New York, NY: John Wiley and Sons), 25-59.
Jaffe, M. J., Telewski, F. W., and Cooke, P. W. (1984). Thigmomorphogenesis: on the mechanical properties of mechanically perturbed bean plants. Physiol. Plant. 62, 73-78. doi: 10.1111/j.13993054.1984.tb05925.x

Latimer, J. G. (1991). Mechanical conditioning for control of growth and quality of vegetable transplants. Hortscience 26, 1456-1461.

Mitchell, C. A., and Myers, P. N. (1995). Mechanical stress regulation of plant growth and development. Hortic. Rev. (Am. Soc. Hortic. Sci.) 17, 1-42.

Morel, P., Crespel, L., Galopin, G., and Moulia, B. (2012). Effect of mechanical stimulation on the growth and branching of garden rose. Sci. Hort. 135, 59-64. doi: 10.1016/j.scienta.2011.12.007

Ohtani, Y. (1950). Studies on the stamping of wheat and barley. Bul. Natl. Agr. Exp. Stn. Jpn. 67, 1-76.

Telewski, F. W. (2006). A united hypothesis of mechanoperception in plants. Am. J. Bot. 93, 1466-1476. doi: 10.3732/ajb.93.10.1466

Walley, J. W., Coughlan, S., Hudson, M. E., Covington, M. F., Kaspi, R., Banu, G., et al. (2007). Mechanical stress induces biotic and abiotic stress response via a novel cis-element. PLoS Genet. 3:e172. doi: 10.1371/journal.pgen.0030172

Conflict of Interest Statement: The author declares that the research was conducted in the absence of any commercial or financial relationships that could be construed as a potential conflict of interest.

Received: 14 July 2014; paper pending published: 18 August 2014; accepted: 21 August 2014; published online: 12 September 2014.

Citation: Iida H (2014) Mugifumi, a beneficial farm work of adding mechanical stress by treading to wheat and barley seedlings. Front. Plant Sci. 5:453. doi: 10.3389/fpls.2014.00453

This article was submitted to Plant Physiology, a section of the journal Frontiers in Plant Science.

Copyright (c) 2014 Iida. This is an open-access article distributed under the terms of the Creative Commons Attribution License (CC BY). The use, distribution or reproduction in other forums is permitted, provided the original author(s) or licensor are credited and that the original publication in this journal is cited, in accordance with accepted academic practice. No use, distribution or reproduction is permitted which does not comply with these terms. 